June 2014

\title{
The Categorical Lucas Rule and the Nuisance and Background Principles Exception
}

Carol Necole Brown

Follow this and additional works at: https://digitalcommons.tourolaw.edu/lawreview

Part of the Constitutional Law Commons, Land Use Law Commons, and the Property Law and Real Estate Commons

\section{Recommended Citation}

Brown, Carol Necole (2014) "The Categorical Lucas Rule and the Nuisance and Background Principles Exception," Touro Law Review. Vol. 30: No. 2, Article 9.

Available at: https://digitalcommons.tourolaw.edu/lawreview/vol30/iss2/9

This Article is brought to you for free and open access by Digital Commons @ Touro Law Center. It has been accepted for inclusion in Touro Law Review by an authorized editor of Digital Commons @ Touro Law Center. For more information, please contact Iross@tourolaw.edu. 


\title{
The Categorical Lucas Rule and the Nuisance AND BACKGROUND PRINCIPLES EXCEPTION
}

\author{
Carol Necole Brown*
}

\section{Table of Contents}

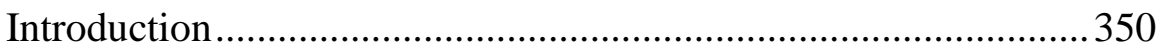

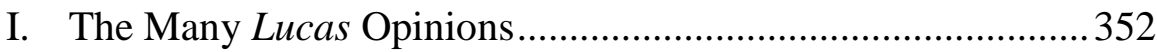

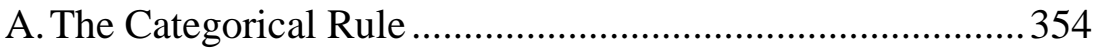

B. The Denominator and Whole Parcel Doctrine ....................356

C. The Nuisance and Background Principles Defense.............359

II. Applying the Nuisance Exception - Four Successful Lucas

Takings Challenges ......................................................... 362

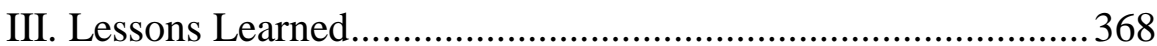

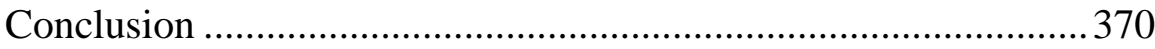

\footnotetext{
* Professor of Law, University of Richmond School of Law. Special thanks to Suzanne B. Corriell, Associate Director for Reference, Research, and Instructional Services at the University of Richmond School of Law and to my research assistant Jessica Barile. Thanks to Professors Daniel Mandelker, Corinna Lain, and David Callies, and to the University of Richmond School of Law and Dean Wendy Perdue for her support of this project. Thank you to my parents, the late Allen S. Brown, Jr. and the late Valerie J. Brown as well as to my husband, Paul Clinton Harris, Sr. and my daughters Reagan Mackenzie Harris and Hannah Madison Harris.
} 


\begin{abstract}
This article examines the seminal 1992 United States Supreme Court decision, Lucas v. South Carolina Coastal Council, ${ }^{1}$ specifically focusing on the Lucas nuisance exception. I surveyed approximately 1,600 reported regulatory takings cases decided since the Lucas decision involving Lucas takings challenges. I identified the statutory nuisance cases in which state and local governments unsuccessfully asserted the Lucas nuisance exception as a defense to the courts'findings of a Lucas taking. This article examines the prospective potential of these cases for assisting private property owners in enhancing private property rights protections within the area of regulatory takings.
\end{abstract}

\title{
INTRODUCTION
}

In this article, I revisit the ad hoc and murky regulatory takings doctrine, reflecting on the 1992 United States Supreme Court decision in Lucas v. South Carolina Coastal Council. ${ }^{2}$ The Lucas Court articulated a categorical regulatory takings rule and an exception to that categorical rule. The categorical rule the Court articulated is that private property owners are entitled to compensation for a taking under the Fifth Amendment Takings Clause when a government "regulation denies all economically beneficial or productive use of land." 3 The Lucas Court acknowledged that the categorical takings rule was subject to what has become well-known as the "nuisance exception." "When a regulation implicates the Lucas categorical takings rule, the government can avoid the duty to pay compensation if it can prove that the "proscribed use interests were not part of [the owner's] title to begin with." In other words, any limitation that is severe enough to deprive a private property owner of all economically beneficial use of the owner's property "cannot be newly legislated or decreed (without compensation), but must inhere in the title itself, in the restrictions that background principles of the State's law of

\footnotetext{
1505 U.S. 1003 (1992).

2 Id.

3 Id. at 1015.

4 Id. at 1022-23 ("It is correct that many of our prior opinions have suggested that 'harmful or noxious uses' of property may be proscribed by government regulation without the requirement of compensation.").

5 Id. at 1027.
} 
property and nuisance already place upon land ownership."6

The Lucas decision exists within the context of two significant United States Supreme Court cases: the 1987 case of First English Evangelical Lutheran Church v. County of Los Angeles, California ${ }^{7}$ and the 2002 case of Tahoe-Sierra Preservation Council, Inc. v. Tahoe Regional Planning Agency. ${ }^{8}$ In First English, the United States Supreme Court stated that temporary takings that "deny a landowner all use of his property, are not different in kind from permanent takings," which clearly must be compensated under the United States Constitution. ${ }^{9}$ Later, in Tahoe-Sierra, which involved two temporary development moratoria, the United States Supreme Court rejected the Lucas categorical takings test. ${ }^{10}$ The Tahoe-Sierra Court concluded that the focus should be on the whole parcel, not a temporal slice. ${ }^{11}$ Additionally, the Tahoe-Sierra Court held that in cases of prospectively temporary takings, the analysis should be under the Penn Central Transportation Co. v. City of New York ${ }^{12}$ regulatory takings balancing test, ${ }^{13}$ not the Lucas categorical test. ${ }^{14}$ The TahoeSierra Court, in articulating the whole parcel doctrine, rejected temporal segmentation and admonished the principle that the denominator in regulatory takings cases should consist of the whole parcel. ${ }^{15}$

To the extent the First English decision left a door open for temporary, prospective closures of private property pursuant to state nuisance abatement statutes to constitute Lucas categorical takings, the Court's later decision in Tahoe-Sierra closed it. ${ }^{16}$ Together, these cases provide an incredibly narrow opening for Lucas takings in this context - one might say, virtually no opening at all.

To prove the point, I looked at 1,600 reported regulatory takings cases decided since the 1992 Lucas decision. ${ }^{17}$ I found only four

Lucas, 505 U.S. at 1029.

7482 U.S. 304 (1987).

8535 U.S. 302 (2002).

9 First English Evangelical Lutheran Church, 482 U.S. at 318; Lucas, 505 U.S. at 101112.

10 Tahoe-Sierra, 535 U.S. at 331-32, 342.

11 Id. at 331.

12438 U.S. 104 (1978).

13 Tahoe-Sierra, 535 U.S. at 331.

14 Id. at 331-32, 342.

15 Id. at 332.

16 See infra Part II.

17 Id. These 1,600 cases represent all cases available in the two major online databases (Lexis and Westlaw) that cited Lucas, 505 U.S. 1003. A total of 1,585 cases were drawn 
cases in which the property owner succeeded in proving that a Lucas categorical taking resulted from the application of a state nuisance abatement statute against the property owner's private property. ${ }^{18}$ In this article, I look at those four cases, examine why the property owners succeeded in mounting their Lucas challenges, and discuss lessons learned when Lucas, First English, and Tahoe-Sierra are considered together. ${ }^{19}$

The discussion proceeds as follows. Part I lays out the many Lucas opinions, explaining why the doctrine is so murky and laying the groundwork for the dispute over the nuisance abatement statutes in the four statutory nuisance cases. Part II examines the four successful applications of the Lucas categorical takings rule that were triggered by application of state nuisance abatement statutes, pursuant to which, private property owners were temporarily denied all use of their property. Part III draws lessons learned from the observations in Parts I and II. I ultimately conclude that these statutory nuisance abatement cases hold little potential for enhancing private property rights protections because they ignore, even subvert, the whole parcel rule and the temporary takings decisions by the United Supreme Court and federal courts since these nuisance abatement cases were decided. ${ }^{20}$

\section{The MANY LuCAS OPINIONS}

In 1986, David Lucas, a South Carolina real estate developer, purchased two lots in a residential subdivision located in South Carolina on the Isle of Palms. ${ }^{21}$ He intended to construct single-family homes on the lots; however, his plans were interrupted when, in 1988, the South Carolina Legislature enacted the Beachfront Management Act ("the Act"), which prohibited Mr. Lucas from placing any "permanent habitable structures" on the lots. ${ }^{22}$ At that time, the

\footnotetext{
from a Lexis Shepard's Report, and 1,607 cases were drawn from a Westlaw Keycite report. The majority of the cases appeared on both reports.

18 Keshbro, Inc. v. City of Miami, 801 So. 2d 864 (Fla. 2001); City of St. Petersburg v. Bowen, 675 So. 2d 626 (Fla. Dist. Ct. App. 1996); State v. Rezcallah, 702 N.E.2d 81 (Ohio 1998); City of Seattle v. McCoy, 4 P.3d 159 (Wash. Ct. App. 2000).

19 See infra Part II.

20 See infra Part III.

21 Lucas, 505 U.S. at 1006-07.

22 Id. at 1007.
} 
Act did not allow for any exceptions. ${ }^{23} \mathrm{Mr}$. Lucas filed a complaint and alleged that the Act's prohibition was a permanent taking of his private property, entitling him to just compensation. ${ }^{24}$ The South Carolina state trial court agreed and ruled that the Act's prohibition on construction of any permanent structure left the lots "valueless" and therefore constituted a total permanent taking of his property. ${ }^{25}$ The South Carolina Supreme Court reversed the trial court. ${ }^{26} \mathrm{Im}$ portant to the South Carolina Supreme Court was Mr. Lucas's concession that the Act was valid and proper in its design to preserve the beaches in South Carolina, a public resource. ${ }^{27}$ The South Carolina Supreme Court ruled that when the State regulates to prevent uses of property that will result in serious harm to the public, the State has no duty to pay compensation under the Takings Clause of the Fifth Amendment of the United States Constitution, regardless of the severity of the effect of the regulation on the value of the private property. $^{28}$

The United States Supreme Court granted certiorari to consider the South Carolina Supreme Court ruling. In a 6-2 opinion, the United States Supreme Court relied upon the South Carolina trial court's determination that Mr. Lucas's lots had been rendered valueless and reversed the South Carolina Supreme Court. ${ }^{29}$

Once in the United States Supreme Court, the Lucas majority opinion, written by Justice Scalia, can be conceptualized as no fewer than three separate rulings. The first ruling is the categorical regula-

23 Id. at 1009. After Mr. Lucas argued his case before the South Carolina Supreme Court, the Act was amended to allow a special permit process. Id. at 1010-11. The United States Supreme Court said that because the South Carolina Supreme Court had earlier decided Mr. Lucas's unconditional and permanent takings case on the merits, Mr. Lucas's permanent takings claim, related to his past deprivation of use was ripe for review by the United States Supreme Court. Id. at 1011-12. The subsequently enacted special permit process would be relevant to any future permit applications, denials, and takings challenges. Lucas, 505 U.S. at 1011.

${ }^{24} I d$. at 1009.

25 Id.

$26 I d$.

27 Id. at 1009-10.

28 Lucas, 505 U.S. at 1010.

29 Id. at 1020, 1030, 1032. Justice Scalia wrote the majority opinion of the Court in which Justices Rehnquist, White, O'Connor and Thomas joined. Id. at 1005 . Justice Kennedy wrote a separate opinion concurring in the judgment. Id. at 1032 (Kennedy, J., concurring). Justices Blackmun and Stevens filed dissenting opinions. Id. at 1036 (Blackmun, J., dissenting), 1061 (Stevens, J., dissenting). Justice Souter filed a separate statement. Lucas, 505 U.S. at 1076 (statement of Souter, J.). 
tory takings test. The second ruling is the denominator issue and the whole parcel rule. The third ruling is the "exception" to the categorical rule - the nuisance and background principles defense. Calling them separate rulings is something of a misnomer as it is exceedingly difficult, perhaps impossible even, to discuss either one without also discussing the others.

The defining components of Justice Scalia's majority opinion have been the source of considerable judicial and scholarly commentary over the years. The majority opinion elicited a separate concurrence by Justice Kennedy, separate dissenting opinions by Justices Blackmun and Stevens, and a separate statement by Justice Souter. ${ }^{30}$ Reflecting on Lucas as one of the seminal takings cases, regardless of one's opinion of the result, it is obvious that these Justices' responses to the majority opinion are compelling and insightful.

\section{A. The Categorical Rule}

The Lucas Court articulated a categorical regulatory takings test: private property owners were entitled to compensation under the Fifth Amendment Takings Clause when a government "regulation denies all economically beneficial or productive use of land." ${ }^{31}$ What might have initially appeared to be a straightforward rule subsequently elicited debate about whether the Lucas categorical rule turned on denial of all value or denial of all use. ${ }^{32}$ In other words, if a regulation eliminated all use but left a property owner with non-speculative or even speculative value, would the Lucas analysis apply or would the Penn Central balancing test apply? ? $^{33}$ Courts and other legal authorities differ on this point. Some contend that the Court's opinion in Tahoe-Sierra endorses loss of value as the Lucas rule. ${ }^{34}$ "Anything less than a 'complete elimination of value,' or a 'total loss,' ... . would require the kind of analysis applied in Penn Central. ${ }^{35}$

30 Id. at 1036 (Blackmun, J., dissenting), 1061 (Stevens, J., dissenting), 1076 (statement of Souter, J.).

31 Id. at 1015-16 (majority opinion).

32 See infra Part III.

33 See infra note 59 and accompanying text.

34 See, e.g., Richard J. Lazarus, Lucas Unspun, 16 S.E. ENVTL. L.J. 13, 28 n.99 (2007) (discussing the Lucas decision in the context of economic value and citing to the TahoeSierra decision and others as interpreting the Lucas decision in the total diminution of all value context).

35 Tahoe-Sierra, 535 U.S. at 330. See also Lingle v. Chevron U.S.A. Inc., 544 U.S. 528, 539 (2005) (stating that "[i]n the Lucas context, of course, the complete elimination of a 
But, other courts and scholars have argued in favor of the loss of use construction of the Lucas categorical takings rule. ${ }^{36}$ An understanding of the Lucas categorical takings rule as only applying when a government regulation deprives an owner of all value would significantly heighten the already substantial impediments to property owners' ability to mount successful Lucas challenges. It is difficult to imagine a situation in which a speculator could not be found who would pay some de minimis amount for a property even if the property had been completely deprived of all development rights and even temporarily deprived of all rights of use. ${ }^{37}$ The law is dynamic, and this dynamism, with the potential for favorable future regulatory

property's value is the determinative factor."); Mayhew v. Town of Sunnyvale, 964 S.W.2d 922, 935 (Tex. 1998) ("A restriction denies the landowner all economically viable use of the property or totally destroys the value of the property if the restriction renders the property valueless. Determining whether all economically viable use of a property has been denied entails a relatively simple analysis of whether value remains in the property after the governmental action.") (citations omitted); Daniel L. Siegel \& Robert Meltz, Temporary Takings: Settled Principles and Unresolved Questions, 11 VT. J. ENvTL. L. 479, 483 (2010) (stating that Penn Central is the proper approach for moratoria because Lucas applies only "when a regulation entirely eliminates a property's value.").

36 See, e.g., Res. Inv., Inc. v. United States, 85 Fed. Cl. 447, 493 (2009) (stating that "there appears to be no genuine issue of material fact that Corps' denial of plaintiffs' 404 permit application left plaintiffs without economically viable use of the project site. Thus, plaintiffs' claim falls under Lucas rather than Tahoe-Sierra and Penn Central, and the Corps' denial of the 404 permit may very well have left plaintiffs without economically viable use of their property.) (emphasis added); Palm Beach Isles Assoc. v. United States, 231 F.3d 1354, 1357 (Fed. Cir. 2000) (appearing to analogize the concepts).

A "categorical" taking is, by accepted convention, one in which all economically viable use, i.e., all economic value, has been taken by the regulatory imposition. Such a taking is distinct from a taking that is the consequence of a regulatory imposition that prohibits or restricts only some of the uses that would otherwise be available to the property owner, but leaves the owner with substantial viable economic use.

Id.

The Lucas Court indicated two factors that are relevant to determining whether property has an economically viable use. The first is the remaining market value of the land. If a regulation renders property "valueless", then no economically viable use remains .... The second factor is the remaining uses available to the landowner. The Court gave little specific guidance for the application of this factor, but did indicate that a regulation that requires land to be left substantially in its natural state deprives the owner of economically viable use.

Ann T. Kadlecek, The Effect of Lucas v. South Carolina Coastal Council on the Law of Regulatory Takings, 68 WASH. L. REV. 415, 427 (1993) (citations omitted).

37 See, e.g., Lucas, 505 U.S. at 1065 n.3 (Stevens, J., dissenting) ("Lucas may put his land to 'other uses' - fishing or camping, for example - or may sell his land to his neighbors as a buffer. In either event, his land is far from 'valueless.' "). 
change for a property owner, creates speculative value at the right price point. And, if Lucas is understood as only applying when there is no value, then it truly is difficult to make the case of a Lucas total taking. An exception to the proposition articulated above would be instances in which the lack of development potential combines with other negative factors such as environmental remediation costs, holding costs, demolition costs, and property tax liability to create "negative value." 38

\section{B. The Denominator and Whole Parcel Doctrine}

Essential to the total takings claim is an analysis of the denominator issue and the whole parcel doctrine. What is the relevant private property interest against which the regulatory impact will be measured? $?^{39}$ The Lucas opinion lacks objective guidance for determining the relevant parcel to constitute the denominator. ${ }^{40}$ The Court acknowledges that the denominator calculation raises a "difficult question" and recognizes it has "produced inconsistent pronouncements" as a consequence of "uncertainty regarding the composition of the denominator." 41 The Lucas majority opinion does not raise the denominator issue as a central concern because the Court was constrained to accept the South Carolina Court of Common Pleas' determination that the South Carolina regulation rendered Mr. Lucas's lot valueless. ${ }^{42}$ Justice Scalia addresses it in dictum, as does Justice Blackmun in his dissent. ${ }^{43}$

Justice Stevens emphasizes the "unsoundness" of the majority opinion in light of the elasticity of the concept of private property rights and the proclivity of owners to manipulate the nature of their property interest, the denominator, post-Lucas, to improve the odds of a Lucas takings challenge. ${ }^{44}$ He explains:

\footnotetext{
38 City of Sherman v. Wayne, 266 S.W.3d 34, 44-45 (Tex. Ct. App. 2008).

39 Lost Tree Vill. Corp. v. United States, 707 F.3d 1286, 1292 (Fed. Cir. 2013) (portending to challenge Penn Central as a seminal decision on the point of the relevant denominator).

40 Lucas, 505 U.S. at 1016 n.7 ("Regrettably, the rhetorical force of our 'deprivation of all economically feasible use' rule is greater than its precision, since the rule does not make clear the 'property interest' against which the loss of value is to be measured.").

${ }^{41} I d$.

42 Id. at 1033-34 (Kennedy, J., concurring); id. at $1016 \mathrm{n} .7$ (majority opinion).

43 Id. at 1016 n.7; Lucas, 505 U.S. at 1036 (Blackmun, J., dissenting).

44 Id. at 1065-66 (Stevens, J., dissenting).
} 
[D]evelopers and investors may market specialized estates to take advantage of the Court's new rule. The smaller the estate, the more likely that a regulatory change will effect a total taking. Thus, an investor may, for example, purchase the right to build a multifamily home on a specific lot, with the result that a zoning regulation that allows only single-family homes would render the investor's property interest "valueless." In short, the categorical rule will likely have one of two effects: Either courts will alter the definition of the "denominator" in the takings "fraction," rendering the Court's categorical rule meaningless, or investors will manipulate the relevant property interests, giving the Court's rule sweeping effect. ${ }^{45}$

Stevens concludes this portion of his dissent by challenging the majority's three rationales for the categorical rule: that total deprivations are analogous to physical takings, that the rule will be rarely applied and therefore will not significantly impact the workings of government, and the risk of undue " singling out" of property owners when regulation leaves these owners with no economically beneficial use of their lands. ${ }^{46}$

In fact, a significant number of the successful Lucas cases are thematically linked by private agreements that the courts found sufficiently reduced the denominator factor so as to trigger a taking. Whether the impacts of these private agreements reflect intentional manipulations or unintended consequences is uncertain. What is clear is that the denominator matters and courts have been willing to honor private property owners' purposeful restrictions on their property interests when ascertaining the denominator for Lucas takings purposes.

Most recently, the Federal Circuit Court of Appeals in Lost Tree Village Corp. v. United States ${ }^{47}$ acknowledged the relevant parcel as a critically antecedent determination in the takings analysis. ${ }^{48}$ Lost Tree, a Florida property owner and land developer, sought a permit from the United States Army Corps of Engineers to fill wet-

\footnotetext{
$45 I d$.

46 Id. at 1066-67.

47707 F.3d 1286.

48 Id. at 1292.
} 
lands on a 4.99-acre parcel ("Plat 57"). ${ }^{49}$ It obtained all applicable state and local approvals, but the Corps denied Lost Tree's wetland fill permit application because it said alternatives were available to Lost Tree that were "less environmentally damaging." 50 Lost Tree claimed the denial was a taking of its property. ${ }^{51}$ The government disagreed and argued that the relevant parcel for the takings analysis was the entire John's Island Community, which consisted of approximately 1,300 acres and which had been developed by Lost Tree years earlier. ${ }^{52}$ Lost Tree argued that the relevant parcel was solely Plat $57 .{ }^{53}$

The court determined that the relevant parcel was Plat 57 alone and that Lost Tree's other holdings in the vicinity of Plat 57 could not be aggregated because Lost Tree had established "distinct economic expectations" for its scattered holdings. ${ }^{54}$ The court articulated the following guidelines for establishing the denominator composition based on its interpretation of relevant Supreme Court and other federal precedent. A court's focus should be on "'the parcel as a whole" doctrine and the doctrine should not be extended to include the property owner's disparate properties that are situated in the vicinity of the property subject to regulation. ${ }^{55}$ Courts should consider the economic expectations of property owners who own several parcels. If such property owners "“treat[] several legally distinct parcels as a single economic unit, together they may constitute the relevant parcel" for the takings analysis. ${ }^{56}$ But, the relevant parcel may be a subset of a larger purchase of land, even contiguous land, when the property owner treats the parcels as "distinct economic units" and develops them at different times. ${ }^{57}$

Of course, the parcel as a whole doctrine predates the Lucas and Lost Tree decisions and can be traced, most famously, back to the landmark United States Supreme Court regulatory takings case of

49 Id. at $1288-90$.

50 Id. at 1291.

51 Id. at 1291.

52 Lost Tree, 707 F.3d at 1288, 1291. Lost Tree developed the John's Island community beginning in 1969 through the mid-1990s. Id. at 1288.

53 Id. at 1291.

54 Id. at 1294.

55 Id. at 1292-93.

56 Lost Tree, 707 F.3d at 1293.

57 Id. 
Penn Central. ${ }^{58}$ The Penn Central Court articulated a three-part regulatory takings test against which most takings cases are judged. ${ }^{59}$ The Penn Central Court pronounced that when applying the threepart test and judging the extent and nature of the government's interference with a property owner's rights, the Court will focus on the nature of the regulation's interference with the owner's rights in the whole parcel on the grounds that " ' $[\mathrm{t}] \mathrm{aking}$ ' jurisprudence does not divide a single parcel into discrete segments and attempt to determine whether rights in a particular segment have been entirely abrogated." ${ }^{60}$ A few years later in Keystone Bituminous Coal Ass' $n$ v. DeBenedictis ${ }^{61}$ the Court reiterated its commitment to the parcel as a whole when constituting the denominator and determining whether a regulation worked a taking of private property for Fifth Amendment purposes. $^{62}$

\section{The Nuisance and Background Principles Defense}

The Lucas Court held that the categorical taking rule was subject to what has become well-known as the nuisance exception. ${ }^{63}$ When a regulation implicates the Lucas categorical taking rule, the government can avoid the duty to pay compensation if it can prove that the "proscribed use interests were not part of [the owner's] title to begin with." ${ }^{64}$ Effectively, the government must demonstrate that the regulation's results could have been achieved judicially under the State's "background principles of nuisance and property law." 65

The Lucas Court also rejected the harm prevention and benefit conferring logic as a basis for distinguishing constitutional takings by regulation that require compensation from regulatory deprivations

58438 U.S. 104.

59 Id. at 124. In deciding whether a government action amounts to a regulatory takings, courts will consider three factors: (1) "the extent to which the regulation" interferes with the property owner's "distinct investment-backed expectations;" (2) the character of the regulatory action, whether its characteristics are similar to government physical invasions; and (3) the regulation's economic impact on the property owner. $I d$.

$60 I d$. at 130.

61 Keystone Bituminous Coal Ass'n v. DeBenedictis, 480 U.S. 470 (1987).

62 Id. at 497.

63 Lucas, 505 U.S. at 1067-68.

${ }^{64} I d$. at 1027.

65 Id. at 1031. See McQueen v. S. Carolina Coastal Council, 580 S.E.2d 116 (S.C. 2003) (relying on the background principles of state property law to reach its holding). 
that do not require compensation. ${ }^{66}$ In so doing, the Court expressly rejected the rationale of the Supreme Court of South Carolina. ${ }^{67}$ The South Carolina Supreme Court held that when the regulation is "designed "to prevent serious public harm," property owners are not entitled to compensation "under the Takings Clause regardless of the regulation's effect on the property's value." ${ }^{\circ 8}$ The South Carolina Supreme Court accepted the state legislature's determination that new construction on Mr. Lucas's lot would threaten an important public resource of the State. ${ }^{69}$ In contrast, the United States Supreme Court unequivocally stated that a legislature's noxious use decree could not undermine the categorical rule that compensation must be paid when regulations result in total takings. ${ }^{70}$ To hold otherwise would compromise the limitations the Court had earlier placed on exercises of the police power without compensation. ${ }^{71}$

One reading of the majority opinion of the United States Supreme Court is that by background principles of nuisance, the Court meant background principles of common law nuisance. The Court emphasized that on remand:

[T]o win its case South Carolina must do more than proffer the legislature's declaration that the uses Lucas desires are inconsistent with the public interest, or the conclusory assertion that they violate a common-law maxim such as sic utere tuo ut alienum non laedas.... [A] "State, by ipse dixit, may not transform private property into public property without compensation . . . ." Instead, as it would be required to do if it sought to restrain Lucas in a common-law action for public nuisance, South Carolina must identify background principles of nuisance and property law that prohibit the uses he now intends in circumstances in which the property is presently found. Only on this showing can the State fairly claim that, in proscribing all such beneficial uses, the Beachfront Management Act is taking

66 Lucas, 505 U.S. at 1026.

${ }^{67} I d$.

68 Id. at 1010.

${ }^{69} I d$.

$70 \quad I d$. at 1026.

71 Lucas, 505 U.S. at 1027 (citing Pennsylvania Coal Co. v. Mahon, 260 U.S. 393, 413 (1922)). 
nothing. $^{72}$

Justice Kennedy's concurring opinion addresses this reading of the majority opinion. Justice Kennedy opines that in determining which reasonable, investment-backed expectations the Constitution will protect through the Takings Clause, our entire legal tradition must necessarily be considered. ${ }^{73}$ "The common law of nuisance is too narrow a confine for the exercise of regulatory power" and the states "should not be prevented from enacting new regulatory initiatives" that respond to our interdependent, complex and changing society. ${ }^{74}$ Moreover, he criticizes the Supreme Court of South Carolina for citing general purposes supporting the enactment of the Beachfront Management Act without also making findings that the regulation was consistent with the property owner's reasonable expectations of use. ${ }^{75}$

Justices Stevens and Blackmun criticize the majority's nuisance exception as elevating common law nuisance over statutory nuisance. $^{76}$ The majority states that any regulation that denies all economically beneficial use of the regulated property "cannot be newly legislated or decreed (without compensation)." "77 Such a regulation "must, in other words, do no more than duplicate the result that could have been achieved in the courts . . . under the State's law of private nuisance, or by the State under its complementary power to abate nuisances that affect the public generally, or otherwise." ${ }^{, 78}$ Justice Stevens writes that the Court's decision "effectively freezes the State's common law, denying the legislature much of its traditional power to revise the law governing the rights and uses of property." 79 And, Justice Blackmun rejects any common law limitation on the State's authority to regulate, without compensation, under the nuisance doctrine. ${ }^{80}$ He argues that common law courts frequently rejected such a limited understanding of the State's power and that the

72 Id. at 1031-32; see also Bowen, 675 So. 2d at 631 (demonstrating one of the successful Lucas nuisance abatement cases discussed in Part II, stating the Lucas nuisance exception was limited to common law nuisances).

73 Lucas, 505 U.S. at 1032 (Kennedy, J., concurring).

74 Id. at 1035.

75 Id.

76 Id. at 1053-55 (Blackmun, J., dissenting); id. at 1068-69 (Stevens, J., dissenting).

77 Lucas, 505 U.S at 1029 (majority opinion) (emphasis added).

78 Id. (emphasis added).

79 Id. at 1068-69 (Stevens, J., dissenting).

80 Id. at 1059-60 (Blackmun, J., dissenting). 
Takings Clause imposes no such limitation. ${ }^{81}$ He rejects the majority's narrowing of the nuisance doctrine in takings jurisprudence and instead relies upon precedent that recognizes the authority "for the legislature to interpose, and by positive enactment to prohibit a use of property which would be injurious to the public." $\$ 82$

Justice Souter anticipated these nuisance abatement type cases in his Lucas statement. He wrote that the Court's opinion assumes cases may arise in which nuisance abatement under state law could deny all economically beneficial use of land ${ }^{83} \mathrm{He}$ was skeptical of the Court's accuracy, stating:

The nature of nuisance law ... indicates that application of a regulation defensible on grounds of nuisance prevention or abatement will quite probably not amount to a complete deprivation in fact. The nuisance enquiry focuses on conduct, not on the character of the property on which that conduct is performed, and the remedies for such conduct usually leave the property owner with other reasonable uses of his property. Indeed it is difficult to imagine property that can be used only to create a nuisance, such that its sole economic value must presuppose the right to occupy it for such seriously noxious activity. ${ }^{84}$

\section{APPLYING THE NUISANCE EXCEPTION-FOUR SUCCESSFUL LUCAS TAKINGS ChallengeS}

Many private property rights advocates lauded the results of the Lucas decision and hoped that the case would infuse land use control with greater private property rights protections. ${ }^{85}$ In contrast,

\footnotetext{
81 Id.

82 Lucas, 505 U.S at 1059 (quoting Commonwealth v. Tewsbury, 52 Mass. 55, 57 (1 Cush. 1846).

${ }^{83}$ Id. at 1077 (statement of Souter, J.).

${ }^{84}$ Id. at 1077-78 (citations omitted).

85 See generally Michael C. Blumm \& Lucus Ritchie, Lucas's Unlikely Legacy: The Rise of Background Principles as Categorical Takings Defenses, 29 HARV. ENVTL. L. REV. 321 (2005). See also Nancie G. Marzulla, A Two-Front Battle for Property Rights, THE CHRISTIAN SCIENCE Monitor (Sept. 18, 1992), http://www.csmonitor.com/1992/0918/18191 .html/(page)/2 ("There is little in the Lucas opinion for opponents of private-property rights to be happy about."); Tom Kenworthy \& Kirstin Downey, South Carolina May Have to Pay Compensation in Property Case, WASH. Post, June 30, 1992, available at 1992 WLNR 5574135.
} 
some environmentalists and Supreme Court "watchers" doubted the case's promise for real impact. ${ }^{86}$ Even as the Court announced the categorical takings test, it predicted that the Lucas decision would apply in "relatively rare situations" 87 and only under the most "extraordinary circumstance[s]." ${ }^{\$ 8}$ The following statutory nuisance abatement cases represent one quarter of one percent of all the cases in which property owners succeeded in making the Lucas challenge.

First, in City of Seattle v. McCoy ${ }^{89}$ the City brought a proceeding to abate the McCoys' operation of their lounge and restaurant (Oscar's II) under a drug nuisance statute. ${ }^{90}$ The McCoys' property interest was a leasehold on the property on which Oscar's II was located. ${ }^{91}$ Oscar's II was found to be a drug nuisance by the trial court and it was ordered closed for one year. ${ }^{92}$ The trial court's order resulted in Oscar's II being place in the court's custody pursuant to an applicable statutory provision. ${ }^{93}$ On appeal, the court found that application of the nuisance statute to the McCoys was a temporary taking. ${ }^{94}$ The court articulated the nuisance exception as "whether the common law of nuisance would have allowed abatement of the lawful business activity against an innocent owner for the illegal drug activities of unidentified business patrons which, when the activities occurred, were unknown and may not have been observable." court determined that the McCoys were innocent owners, that they acted reasonably to attempt to abate the nuisance, and that the com-

${ }^{86}$ See generally Ronald H. Rosenberg, The Non-Impact of the United States Supreme Court Regulatory Takings Cases on the State Courts: Does the Supreme Court Really Matter?, 6 FORDHAM ENVTL. L.J. 523 (1995) (reviewing state court cases relying on the Lucas decision and stating that the vast majority do not find regulatory takings); see Lazarus, supra note 34, at 23 (stating that the Lucas "opinion was virtually 'dead on arrival' in terms of its potential to establish significant precedent favorable to the property rights movement."); but see Victoria Sutton, Constitutional Taking Doctrine - Did Lucas Really Make a Difference?, 18 PACE ENVTL. L. Rev. 505, 516-17 (2001) (discussing Lucas's narrow direct application but its "profound indirect impacts").

87 Lucas, 505 U.S. at 1018.

88 Id. at 1017.

894 P.3d 159 (Wash. Ct. App. 2000).

90 Id. at 161.

91 Id. at 162.

$92 I d$. at 161.

93 Id.

94 McCoy, 4 P.3d at 166-67 ("By virtue of the abatement order ... the building [is] in the custody of the court. Therefore, the McCoys are not in possession. They cannot put the property to any economically viable use pending the expiration of one year ....").

95 Id. at 167. 
mon law nuisance exception in that state was based upon whether the owners, given their constructive and actual knowledge, took reasonable steps to abate the nuisance. ${ }^{96}$ The court held that the City did not meet its burden of proving a common law nuisance according to the Lucas exception. ${ }^{97}$

McCoy was the only nuisance exception case in which the owner restricted the denominator by acquiring only a leasehold interest. $^{98}$ The First English dissent likely imagined this type of case when describing the qualities of temporary Lucas takings. ${ }^{99}$ A leasehold of sufficiently short remaining duration and a sufficiently lengthy nuisance abatement closure when combined with other factors such as insufficient tailoring and acquiescence or participation by the owner in the nuisance activity might be sufficient to overcome the First English dissent and the Tahoe-Sierra Court's caution against temporal segmentation in the application of the Lucas categorical rule and its nuisance exception. ${ }^{100}$

Second, City of St. Petersburg v. Bowen ${ }^{101}$ involved application of a nuisance abatement statute to the property owner's fifteenunit apartment complex. ${ }^{102} \mathrm{Mr}$. Bowen owned a fee simple in the apartment complex which was ordered closed for one year after being found to constitute a statutory nuisance because of purported drug use by tenants of the apartment complex and others who were on the property. ${ }^{103}$ The court found a temporary Lucas taking because the building could not be put to any economic use during the one-year closure period. ${ }^{104}$ The court stated that the Lucas exception limited the matter to common law nuisances and that no common law nuisance doctrine prohibited using a building for rental purposes. ${ }^{105}$

\footnotetext{
96 Id. at 171.

97 Id. at 171-72.

98 See supra Part II.

99 First English Evangelical Lutheran Church, 482 U.S. at 331 (Stevens, J., dissenting) (discussing regulations that "remain in effect for a significant percentage of the property's useful life.").

100 Tahoe-Sierra, 535 U.S. at 315 (finding that Penn Central and not Lucas was the appropriate takings test to apply after considering the temporary nature of the regulation and the "average holding time" of the property in question).

101675 So. 2d 626 (Fla. Dist. Ct. App. 1996).

102 Id at 629.

103 Id. at 627-28.

104 Id. at 629; see supra Part I-A (discussing the value versus use interpretations of the Lucas opinion).

105 Bowen, 675 So. $2 \mathrm{~d}$ at 631.
} 
Third, Keshbro, Inc. v. City of Miami ${ }^{106}$ consolidated two cases, City of St. Petersburg v. Kablinger ${ }^{107}$ and City of Miami v. Keshbro ${ }^{108}$ ("the Stardust Motel"). The property interest held by the owners was a fee simple absolute in an apartment complex and in a motel, respectively. In both cases, the court found that the closure orders deprived the owners of all economically beneficial use of their property. ${ }^{109}$ The issue for the court and the reason for the different ultimate results was the question of specific tailoring of the closure orders to "abate the objectionable conduct, without unnecessarily infringing upon the conduct of a lawful enterprise."110

The court found that the regulation in Kablinger was a Lucas categorical taking and that the Lucas nuisance exception did not apply. ${ }^{111}$ But, in Keshbro, the court said the nuisance exception did apply and was a defense to the property owner's claim of a Lucas categorical taking. ${ }^{112}$ The six-month temporary closing of the apartment in Kablinger, according to the court, was not attended by the same extensive record indicating that the nuisance (drug activity) had become inextricable from the operation of the Stardust Motel in Keshbro. ${ }^{113}$ Absent such a record, the court found the closure order for one year in Kablinger was not sufficiently tailored to benefit from the Lucas nuisance exception. ${ }^{114}$ In contrast, the court found that the drug and prostitution activity at the Stardust Motel in Keshbro had become "part and parcel" of the Stardust's operation and that the City of Miami had failed to eradicate this nuisance activity despite patient attempts. ${ }^{115}$

Finally, the Ohio case of State ex rel. Pizza v. Rezcallah ${ }^{116}$ involved three consolidated cases in which the property interest was a fee simple absolute in residential property. ${ }^{117}$ In all three cases, it was alleged that non-owner residents, while occupying three different

\footnotetext{
106801 So. 2d 864 (Fla. 2001).

107730 So. 2d 409 (Fla. Dist. Ct. App. 1999).

108717 So. 2d 601 (Fla. Dist. Ct. App. 1998), aff'd, 801 So. 2d 864 (Fla. 2001).

109 Keshbro, 801 So. 2d at 868-70.

110 Id. at 876.

111 Id. at 876-77.

$112 I d$. at 876.

113 Id. at 876-77.

114 Keshbro, 801 So. 2d at 877.

115 Id. at 876.

116702 N.E.2d 81 (Ohio 1998).

117 Id. at $83,85$.
} 
residential properties, committed drug-related felonies. ${ }^{118}$ Each property owner was found to have taken affirmative, good faith action to investigate and remove offending residents. ${ }^{119}$ The court found that application of the nuisance abatement statute was a taking as it required, upon the finding of a nuisance, the issuance of a temporary, one-year closure order forbidding use of the property for any purpose. ${ }^{120}$ Additionally, the court held that in each of the three cases, the closings, under the facts, would be unconstitutional forfeitures and seizures of property in violation of the federal Fifth Amendment Takings Clause and Fourteenth Amendment Due Process Clause. ${ }^{121}$ The court distinguished these cases from Bennis v. Michigan ${ }^{122}$ in which the United States Supreme Court held that forfeiture of property, even as applied to good-faith property owners, was not a Fifth Amendment Taking requiring the government to pay compensation because such property is acquired, not by the exercise of the power of eminent domain, but through forfeiture. ${ }^{123}$

The court distinguished Bennis from the facts of this case in four ways. First, the court said the plaintiff in Bennis conceded that her property was subject to civil forfeiture and only argued the issue of compensation; therefore, the Court was not required to "evaluate the propriety of the forfeiture itself." 124 Second, it was important to the majority in Bennis that the statutory framework allowed judicial discretion to determine the propriety of the forfeiture; in contrast, the Ohio statutory framework did not allow for a similar exercise of discretion. ${ }^{125}$ Third, unlike the property owners in State ex rel. Pizza, the property owner in Bennis did not offer evidence of affirmative actions that she took to avoid having her property used for an illegal purpose nor did she offer evidence of any action that she took to

\footnotetext{
118 Id. at $83-86$.

119 Id. at $85-86$.

120 Id. at 88-89.

Nor is the closure-order provision saved from constitutional infirmity by the availability of judicial release through the filing of a bond in the full value of the property. Deprivation of the use of resources equal to the value of the property is as much a taking as is deprivation of the use of the property itself. 
abate the use of her property for an illegal purpose. ${ }^{126}$ And finally, the court noted that the remedial objectives achieved through forfeiture in the Bennis case, revenue generation, though concededly modest, would not be achieved by a temporary closure. ${ }^{127}$

Interestingly, the state decisions discussing the Lucas taking in the nuisance abatement context all involve statutory nuisances. Despite the apprehension about statutory nuisances that can be read into the Lucas majority opinion, ${ }^{128}$ subsequent courts and scholars seem to have accepted that the decision is not limited to common law nuisances. ${ }^{129}$ However, these cases do not turn on the distinction between common law and statutory nuisances that Justices Stevens and Blackmun emphasize in their dissents. ${ }^{130}$ The state courts, in their analysis of the merits, tend to emphasize the breadth of the application of the nuisance statute (the extent to which non-nuisance activities are also prohibited) and the bona fides of the property owners. ${ }^{131}$

Additionally, a common theme in the nuisance abatement cases is the courts' insistence upon specific tailoring and circumspectness in the application of nuisance abatement statutes and temporary closure orders, especially in the context of property owners who were not involved in the conduct that was the subject of the statute. Absent this specific tailoring, the courts have declined to apply the nuisance exception. ${ }^{132}$

Finally, the denominator issue and the whole parcel rule were not prevalent in these nuisance abatement cases. One reading of these decisions is that the state courts essentially determined to abandon the whole parcel rule and treat the Lucas decision as a categorical rule of compensation upon a total deprivation of all use for a temporary pe-

\footnotetext{
$126 I d$.

127 Id.

128 See supra Part I-C.

129 See, e.g., Blumm, supra note 85, at 334. ("Some lower courts seem to have taken Justice Kennedy's concurrence to heart, ruling that 'background principles' nuisances include more than just the common law variety."); Richard J. Lazarus, Putting the Correct "Spin" on Lucas, 45 STAN. L. REv. 1411, 1426 (1993) (stating that "the majority's intimations that the background principles must be supplied by judge-made common law, rather than by legislative or regulatory enactment, will probably not survive review in the future.").

130 See supra Part I-C.

131 See supra Part II.

132 In the spirit of Justice Souter's observation on this point, in Keshbro, Inc. v. City of Miami, the court found in one of the two consolidated cases that the nuisance exception did apply because the nuisance activity could not be extricated from the non-nuisance activity and therefore, the order of closure was reasonable. See supra notes 77, 79, and accompanying text.
} 
riod of time. The next logical step was to temporally segment the property, which allowed the temporary abatement of all use pursuant to the nuisance abatement statutes to trigger the temporary Lucas takings that the courts found in most of the cases.

\section{LESSONS LEARNED}

Prospectively, these statutory nuisance abatement cases hold little traction for enhancing private property rights protections because they ignore, even subvert, the whole parcel rule and the temporary takings guidance proffered by the Supreme Court and federal courts since these cases were decided. First, all of the statutory nuisance cases were decided prior to 2002 when the United States Supreme Court decided Tahoe-Sierra Preservation Council, Inc. v. Tahoe Regional Planning Agency. ${ }^{133}$ In that case, the United States Supreme Court rejected the Lucas challenge to development moratoria totaling thirty-two months and concluded that the Penn Central ${ }^{134}$ regulatory takings balancing test should be applied to the facts instead. ${ }^{135}$ The Court rejected temporal segmentation and admonished that the denominator in regulatory takings cases should consist of the whole parcel, stating, "[1] ogically, a fee simple estate cannot be rendered valueless by a temporary prohibition on economic use, because the property will recover value as soon as the prohibition is lifted."136 The Court concluded that in cases such as the one before it, where property owners were faced with prospectively temporary takings, the focus should be on the whole parcel, not a temporal slice, and the analysis should be under Penn Central and not Lucas. ${ }^{137}$

The significance of the temporary nature of the taking to the Tahoe-Sierra Court should not be underplayed. Lucas was a permanent and unconditional takings case under the statute as written at the time the case was heard by the South Carolina Supreme Court. ${ }^{138}$ In contrast, all of the statutory nuisance cases were expressly and pro-

133 The case was decided on April 23, 2002. 535 U.S. 302. The decision in City of Seattle v. McCoy, the most recent of the nuisance abatement cases, was filed on April 1, 2002. 48 P.3d 993 (Wash. Ct. App. 2002).

134438 U.S. 104.

135 Tahoe-Sierra, 535 U.S. at 334.

136 Id. at 332.

137 Id. at 329, 342.

138 See supra note 23 and accompanying text. 
spectively temporary closures and argued as temporary takings. ${ }^{139}$ Post Tahoe-Sierra, these prospectively and expressly temporary regulatory takings claims will be difficult to win under the Lucas analysis where the property owner owns the property in fee.

While the federal courts have not foreclosed the possibility of temporary categorical takings, the area has been circumscribed. ${ }^{140}$ In First English Evangelical Lutheran Church of Glendale v. County of Los Angles, California, the United States Supreme Court held that temporary takings are compensable. ${ }^{141}$ The Court cited several physical takings cases as "reflect[ing] the fact that 'temporary' takings which . . . deny a landowner all use of his property, are not different in kind from permanent takings, for which the Constitution clearly requires compensation." 142 However, the dissent noted that the physical takings cases were "inapposite" for the proposition that temporary and permanent takings are indistinguishable and further observed that for a temporary restriction to effect a taking, the regulatory restriction must be substantial and effective "for a significant percentage of the property's useful life." 143

First English Evangelical was, and is, a significant Supreme Court decision because of its contribution to establishing the compensability of temporary takings. Though decided more than a decade before all but one of the four nuisance exception cases, the state courts virtually ignored the decision, with the exception of the court

\footnotetext{
139 See supra Part II.

140 Res. Invs. Inc., $85 \mathrm{Fed} . \mathrm{Cl}$. at 481-82.

Further contrary to defendant's argument, the Federal Circuit has continually refused to hold that categorical treatment is inapposite for a temporary taking, despite numerous opportunities and invitations to do so. In the context of a physical invasion, to which the Supreme Court compared the totality of the taking in Lucas, " "permanent' does not mean forever, or anything like it. A taking can be for a limited term-what is 'taken' is, in the language of real property law, an estate for years, that is, a term of finite duration as distinct from the infinite term of an estate in fee simple absolute."
}

Id.; see infra note 144 and accompanying text (discussing the dissent's articulation of when a temporary taking can rise to the level of a categorical taking).

${ }^{141}$ First English Evangelical Lutheran Church, 482 U.S. at 318.

142 Id.

143 Id. at 331 (Stevens, J., dissenting); see also Seiber v. United States, 364 F.3d 1356, 1368 (Fed. Cir. 2004) ("In Boise Cascade we explained that the Supreme Court may have only 'rejected [the] application of the per se rule articulated in Lucas to temporary development moratoria,' and not to temporary takings that result from the rescission of a permit requirement or denial.") (citations omitted). 
in Keshbro, Inc. v. Miami. ${ }^{144}$ The court in Keshbro distinguished First English from the nuisance abatement cases, stating that the property owners in the nuisance abatement cases were "being deprived of a property's dedicated use" unlike in First English, a temporary moratoria case. ${ }^{145}$ Thus, the court effectively ignored the whole parcel rule and treated prospectively temporary regulations as the equivalent of retrospectively temporary regulations for purposes of the Lucas takings analysis. ${ }^{146}$

Moreover, to the extent that the Lucas categorical rule only applies when there is complete loss of value, temporary elimination of use under the statutory foreclosure statutes with retention of future use and therefore speculative future value would seem to foreclose the Lucas challenge and require the Penn Central kind of analysis. In regulatory takings matters, "the parcel as a whole" analysis is the federal standard. ${ }^{147}$ Thus, with this understanding, there can only be a Lucas categorical regulatory taking if the land as a whole parcel is deprived of all value or use.

\section{CONCLUSION}

The structure of the Lucas opinion itself and of subsequent Supreme Court decisions places substantial, contemporary, limitations on the viability of the Lucas takings claim in the statutory nuisance abatement context. Most of the successful Lucas challenges are special circumstances cases in which an intervening act or circumstance triggers the Lucas taking. The statutory nuisance abatement cases are likely outliers and prospectively hold little potential for enhancing private property rights protections in the future.

\footnotetext{
144 Keshbro, 801 So. 2 d at 873-74.

145 Id. at 874.

146 Id. at 873-74.

147 Lost Tree Vill. Corp., 707 F.3d at 1292-93; Seiber, 364 F.3d at 1368.
} 